\title{
Bio-rational insecticides toxicity against Liriomyza trifolii (Burgess) damaging Cantaloupes, Cucumis melo var. cantalupensis
}

\author{
D. Srinivasa Reddy* \\ Horticulture Research Station, DRYSRHU, Ananthrajupeta - 516105 (Andhra Pradesh), \\ India

\section{Madhumati} \\ Horticulture Research Station, DRYSRHU, Ananthrajupeta - 516105 (Andhra Pradesh), \\ India

\section{R. Nagaraj} \\ Horticulture Research Station, DRYSRHU, Ananthrajupeta - 516105 (Andhra Pradesh), \\ India
}

*Corresponding author. E-mail: dsr2020@gmail.com

\begin{abstract}
Field experiments were conducted for two seasons (2015-16 and 2016-17) to evaluate bio-rational insecticides against leaf miner (Liriomyza trifolii) damaging cantaloupes and it was found that among various insecticides viz. spinosad 45SC@0.32 $\mathrm{ml} / \mathrm{l}$, abamectin 1.9EC @0.3ml/l, fipronil 5SC@2ml/l, fipronil 80WG@0.15g/l, cyantraniliprole 10OD@ 1.8ml/l, triazophos 40EC@2ml/l, diafenthiuron 50WP@1g/l, novaluron 10EC@1ml/l, neem soap@7.5g/l, pongamia soap@7.5g/l, azadirachtin 1\%EC @5ml/l, abamectin (1.03 -2.33 mined leaves/10ft row) and spinosad (1.18-3.33 mined leaves/10ft row) in both the seasons prove to be highly effective in minimising the damage. All the treatments had significant effect on the yield as compared to control but among treatments they were non -significant in first season which was not the case in second season where highest yield was noted in spinosad (11.43t/acre) followed by azadirachtin(9.79t/acre) and abamectin (9.67t/acre). Though there was variation in yield within these treatments but they were statistically on par with each other. Similarly the treatments were on par with each other with respect to number of fruits per vine, fruit weight, TSS and number of seeds set per fruit. The overall findings indicate that the molecules viz., abamectin and spinosad can be recommended to control leaf miner in cantaloupes to achieve an appreciable yield.
\end{abstract}

Keywords: Abamectin, Cantaloupes, Liriomyza trifolii, Spinosad

\section{Article Info}

DOI:10.31018/jans.v10i4.1898 Received: September 18, 2018 Revised: November 21, 2018

Accepted: November 27, 2018

\section{How to Cite}

Reddy, D.S. et al. (2018).

Bio-Rational insecticides toxicity against Liriomyza trifolii (Burgess) damaging Cantaloupes, Cucumis melo var. cantalupensis. Journal of Applied and Natural Science, 10(4): 1271-1275

\section{INTRODUCTION}

Cucurbits are one of the most widely grown vegetable crops during kharif and summer season in all parts of the country and due to development and introduction of new hybrids of melons and cantaloupes, the cultivation of these crops in Andhra Pradesh is expanding and farmers are reaping benefits in short duration. The introduction of new mechanization practices in horticulture viz., drip irrigation, mulching and fertigation were being adopted on larger scale by the growers due to encouragement and financial support by the public sector departments by providing subsidies, so that even small and marginal farmers are also able to earn the profit by cultivating these very short duration (55-60 days) and high profitable crops. At the same time, the pest scenario has been changing and the insect pests which were restricted to certain group of cucurbits also started damaging the melons and cantaloupes and among them, a regular and severe damage insect pest attacking these crops is serpentine leafminer. Serpentine leafminer, Liriomyza trifolii (Burgess) is a polyphagous insect and attacks a wide range of vegetables and ornamentals all over the world (Parrella, 1987, Seal et al. 2002). Both larvae and adults damage the host plants. The larvae feed on leaf mesophyll and reduce chlorophyll content. The adults also damage the leaves by puncturing them for feeding and oviposition (Parrella et al., 1985). Biological control of the leaf miners has had limited success so far and at present, chemical control is the main tactic in managing these pests (Fathipour et al., 2006). Liriomyza has a potential to develop a resistance to insecticides and this potential affects effective control of leafminers (Parrella, 1987). The strong capability of $L$. trifolii to develop resistance to insecticides also made a displacement of other species on several crops possible (Schuster and Everett, 
1983). It was also demonstrated that $L$. trifolii is more tolerant to insecticides than other agromyzid species (Parrella and Keil, 1985). Cyromazine, abamectin and spinosad are known as effective compounds for the control of leafminers (Ferguson, 2004; Prijono et al., 2004). Abamectin is a mixture of two avermectins and is classified in the IRAC group 6 or glutamate-gated chloride channel allosteric modulators (IRAC, 2015), and they hinder neural and neuromuscular transmissions (Ananiev et al. 2002). Similarly spinosad is found effective against thrips, flies, leaf miner, caterpillars/worms damaging leaf and fruit with a unique mode of action and showing low toxicity towards birds and mammals (Van Leeuwen et al., 2006) and been used for controlling insect pests of vegetables, fruits and cotton. The less risk insecticide that have potential to manage $L$. trifolii is Azadirachtin, a botanical acts as an insect growth regulator that prevents molting and hence is effective against immature stages (Koul, 1999). The growers adopt pesticide spray to manage leaf miner only when larval mines are visible on the leaves and generally make several applications in the growing season. Determining the residual activity of insecticides with reduced risk will be useful in avoiding unnecessary chemical treatments. The conventional insecticide for example triazophos recommended against serpentine leaf miner (Udyana Panchagam,2015) on cucurbits gave low to moderate control in the farmer's field and hence there is a need to test newer biorational and safer molecules that have novel mode of action (ZREAC Proceedings, 2016). In justification of this background, the present study was undertaken to know the residual effect of biorational insecticides, namely abamectin, spinosad, novaluron, botanicals (neem and pongamia), and a new novel compound, cyantraniliprole on $L$. trifolii damaging cantaloupes.

\section{MATERIALS AND METHODS}

Cantaloupe crop was raised on fine tilth red loamy soil beds of $1 \mathrm{~m}$ width, $50 \mathrm{~m}$ length and $15 \mathrm{~cm}$ height with drip irrigation facilities and these beds were covered with black polythene mulching sheet having thickness of $25 \mu$. The hybrid seed" Kundan" was procured from Known U Seed Company Ltd., Pune. There were in total eleven treatments (spinosad 45SC@0.32ml/l, abamectin 1.9EC @0.3ml/l, fipronil 5SC@2ml/l, fipronil 80WG@0.15g/l, cyantraniliprole100D@1.8ml/l, triazophos 40EC@2ml/l, diafenthiuron 50WP@1g/ I, novaluron 10EC@1ml/l, neem soap@7.5g/l, pongamia soap@7.5g/l, azadirachtin 1\%EC @5ml/l) and a control. A 2" hole was made using plastic pipe and seeds were sown at the rate of 1 seed per hole to a depth of 1 to $1 \frac{1 / 2}{2}$ " in the III week of February in both the seasons (2015-16 and 2016-17 summer seasons). The seeds germinated after 7 to 8 DAS and when the crop was $15-$ 16 days old i.e., 2-3 leaf stage, the treatments were imposed. The experiment was conducted at Horticultural Research Station, Dr.YSR Horticultural University Anantharajupet, Railway Kodur, Kadapa District, AP. Three replications were maintained for each treatment. The data with respect to leaf miner incidence was recorded on the number of mined leaves for every $10 \mathrm{ft}$ row and subjected to statistical analysis. Fruits were harvested when there was complete formation of net on the fruit. The yield parameters viz., number of fruits per vine, average individual fruit weight $(\mathrm{g})$, yield per acre (tonnes) and a important fruit quality parameter i.e., TSS was also recorded for both the seasons.

\section{RESULTS AND DISCUSSION}

Cantaloupes leaf damage from leaf miner activity was minimal when evaluated at 7,14 and 21 days

Table 1. Novel insecticide toxicities against Liriomyza trifolii damaging cantaloupes.

\begin{tabular}{|c|c|c|c|c|c|c|}
\hline \multirow{3}{*}{ Treatments } & \multicolumn{6}{|c|}{ Number of mined leaves/10ft row } \\
\hline & \multicolumn{3}{|c|}{ 2015-16 (I season) } & \multicolumn{3}{|c|}{$2016-17$ (II season) } \\
\hline & 7DAS & 14DAS & 21DAS & 7DAS & 14DAS & 21DAS \\
\hline Spinosad 45SC & $2.67^{* *}\left(1.91^{*}\right)$ & $3.00(1.98)$ & $3.33(2.07)$ & $1.92(1.38)$ & $1.18(1.08)$ & $2.17(1.63)$ \\
\hline Abamectin 1.9EC & $2.00(1.73)$ & $2.00(1.73)$ & $2.33(1.82)$ & $1.03(1.42)$ & $1.85(1.66)$ & $1.74(1.64)$ \\
\hline Fipronil 5SC & $5.33(2.51)$ & $6.00(2.64)$ & $6.67(2.76)$ & $4.77(2.17)$ & $5.08(2.05)$ & $6.85(2.62)$ \\
\hline Fipronil 80WG & $4.67(2.37)$ & $5.00(2.44)^{\prime}$ & $5.67(2.58)$ & $4.52(2.11)$ & $5.73(3.29)$ & $6.63(2.57)$ \\
\hline Cyantraniliprole & $3.00(2.00)$ & $3.33(2.07)$ & $4.33(2.30)$ & $3.16(2.03)$ & 2.81(1.84) & $3.10(1.76)$ \\
\hline Triazophos 40EC & $5.67(2.58)$ & $6.33(2.69)$ & $7.00(2.82)$ & $3.17(1.77)$ & $6.63(2.57)$ & $7.07(2.66)$ \\
\hline $\begin{array}{l}\text { Diafenthiuron } \\
50 \text { WP }\end{array}$ & $6.67(2.76)$ & $8.00(3.00)$ & $8.33(3.054)$ & $5.47(2.34)$ & $8.43(2.90)$ & $9.27(3.04)$ \\
\hline Novaluron 10EC & $6.33(2.69)$ & $6.67(2.75)$ & $8.00(2.882)$ & $4.27(2.05)$ & $5.67(2.38)$ & $5.73(2.39)$ \\
\hline Neem soap & $9.00(3.07)$ & $8.50(2.99)$ & $10.00(3.24)$ & 7.07(2.66) & $8.77(2.98)$ & $8.67(2.94)$ \\
\hline Pongamia soap & $8.00(2.90)$ & $9.50(3.16)$ & $11.00(3.38)$ & $9.60(2.35)$ & $10.28(3.35)$ & $9.61(3.25)$ \\
\hline Azadirachtin 1\%EC & $5.00(2.44)$ & $6.33(2.69)$ & $7.00(2.825)$ & $4.17(2.04)$ & $5.53(2.35)$ & $7.17(2.67)$ \\
\hline Control & $8.33(3.04)^{\prime}$ & $10(3.30)$ & $10.33(3.35)$ & $8.67(2.94)$ & $14.57(3.81)$ & $15.60(3.95)$ \\
\hline$C D(P=0.05)$ & 0.252 & 0.406 & 0.313 & 1.60 & 1.26 & 0.67 \\
\hline
\end{tabular}

*Figures in parenthesis represent square root transformation values; ${ }^{* *}$ Values out of parenthesis are mean of three replications; DAS-Days after spray 
Reddy, D.S. et al. / J. Appl. \& Nat. Sci. 10 (4): 1271-1275 (2018)

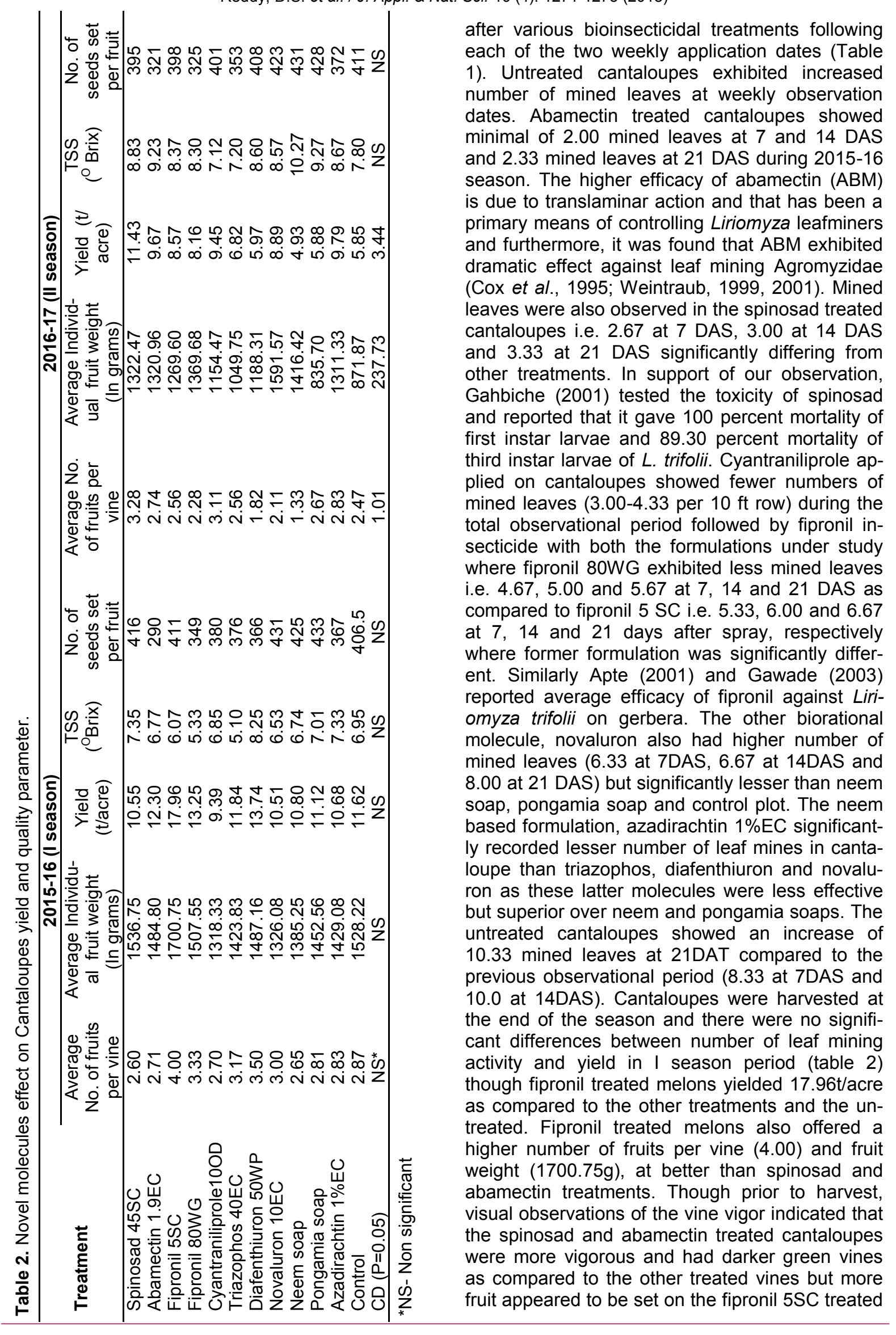


vines and the fruit appeared slightly larger. There was no significant difference in treatments with respect to TSS and number of seeds set per fruit though cantaloupes harvested from diafenthiuron sprayed plot recorded highest TSS of $8.25^{\circ}$ brix followed by spinosad of $7.35^{\circ}$ Brix and lowest in fipronil $80 \mathrm{WG}\left(5.35^{\circ}\right.$ Brix) and in control, a 6.95 ${ }^{\circ}$ Brix higher than the latter treatment.

All the treatments were significantly superior over control (15.60 mined leaves per $10 \mathrm{ft}$ row at 21DAS) at three observations recorded in second season and the data for leaf mining from second season depicted a similar trend showing that abamectin had lowest number of mined leaves i.e. 1.03 , and 1.74 per $10 \mathrm{ft}$ row at 7 and 21 days after spray followed by spinosad (1.92 and 2.17 per $10 \mathrm{ft}$ row at 7 and 21 DAS) and both were on par with each other at all the three observational periods. In support of our observations, Desai Niranjan Ravsaheb (2013) results on efficacy of different insecticides on cucumber through foliar sprays showed that abamectin 1.9EC@0.00057\% was most effective treatment for suppression of Liriomyza trifolii with maximum crop growth and yield. The other treatments viz., cyantraniliprole, showed significantly lower number of mined leaves compared to botanicals and control. Among the botanicals, azadirachtin sprayed cantaloupe plot significantly registered lower number of mined leaves (7.17) as compared to neem soap (8.67) and pongamia soap (9.61) at 21 DAS but all these treatments produced higher leaf mining activity than novaluron, 4.27, 5.67 and 5.73 mined leaves per $10 \mathrm{ft}$ row at 7,14 and 21 days after spray, respectively. The widely used insecticide for leaf miner control triazophos though initially (7DAS) showed less leaf mining (3.17) but increased at 14 and 21 DAS but significantly less than diafenthiuron treatment indicating that this latter insecticide is not effective against serpentine leaf miner. The information on yield and quality parameters can be revealed from table 4 that maximum number of fruits per vine (3.28) were observed in spinosad 45SC treatment followed by cyantraniliprole 10OD (3.11), azadirachtin (2.83), abamectin(2.74), pongamia soap (2.67), fipronil $5 \mathrm{SC}(2.56)$ and triazophos $40 \mathrm{EC}(2.56)$, control (2.47) fipronil 5SC (2.56), fipronil 80WG (2.28) and novaluron(2.11) and though there was variation in number of fruits produced in different treatments but they were on par with each other except in neem soap (1.33) applied plot which recorded minimum number of fruits. Similarly maximum fruit weight of 1591.57 grams was recorded in novaluron treatment followed by neem soap (1416.42g) and lowest weight of $835.70 \mathrm{~g}$ was noted in pongamia soap sprayed plot. With respect to yield, though spinosad gave maximum fruit yield of 11.43 tonnes per acre followed by azadiracthin (9.79t/acre), abamectin (9.67t/acre) but all the treatments were insignificant with each other. There was no significant difference in treatments with respect to TSS and number of seeds set per fruit though fruits harvested from neem soap sprayed plot recorded highest TSS of $10.27^{\circ}$ Brix and lowest in cyantraniliprole 100D treated plot $\left(7.12^{\circ} \mathrm{Brix}\right)$. It is worth to note that triazophos, neem soap and diafenthiuron treated cantaloupes appeared more chlorotic and less vigorous and these insecticides exhibited phytotoxic symptoms on leaves during II season. The botanical based insecticides mainly azadirachtin compared to pongamia also showed good efficacy against leaf miner in both the seasons and to further add Ganapathy et al., (2010) reported NSKE@ 4-5\% and azadirachtin applications were found to be the one of the promising treatments after insecticides in controlling $L$. trifolii on cucumber and tomato and the botanical was not an ovipositional deterrent, but killed first instar larvae. The field findings from both the seasons study indicate that abamectin was the most effective insecticide molecule with low leaf mines damaged by serpentine leaf miner followed by spinosad and with respect to fruit yield both were on par with each other and in strong support of our research findings, Similarly Shashan et al. (2016) recorded lowest number of mines, larvae and pupae with abamectin and spinosad and are potential biorational insecticides to manage $L$. trifolii on snap bean. A further observation with respect to fruit yield also depicted a similar trend with our data that though maximum fruit yield was recorded in abamectin but it was at par with spinosad. Our data observation also had other findings that though there was variation in terms of efficacy against leaf mining activity with each treatment but that could not influence the yield significantly among the treatments and in support, Kotze and Dennill (1996) observed that the phenology of $L$. trifolii feeding (before or during and after flowering) had no effect and the effect of herbivory by $L$. trifolii was not obscured by any relationship between fruit production and growth of the tomato plants.

Our results when coupled with findings from previous tests conducted on tomato, cucumber indicate that abamectin and spinosad can be considered an excellent replacement for organophosphate insecticides in foliar sprays in cantaloupes as spinosad (a metabolite) is a mixture of spinosyns $A$ $\& D$, the soil fermentation products of the soil Saccharopolyspora spinosa Mertz and Yao, and is active at low application rates, has low mammalian toxicity, and reduced impact on natural enemies (DowElanco 1994; Stark et al., 2004). These insecticides, abamectin and spinosad are environment friendly for successful management of serpentine leaf miner, Liriomyza trifolii in different growing regions in India where they are serious economic pests as well as for the eradication of 
accidental introductions into other crops.

\section{Conclusion}

In conclusion to manage serpentine leaf miner, Liriomyzia trifolii in cantaloupes, the tested biorational insecticides, spinosad 45SC@ 0.32ml/l and abamectin 1.9EC@0.3ml/l proved to be highly effective by registering lower mined leaves i.e. 3.33 and $2.17,2.33$ and 1.74 at 21 days after spray with yield of 10.55 ; 11.43 t/ha and 12.30 ; 967tha for first and second seasons, respectively against the insect pest under study and can be well recommended for growers.

\section{REFERENCES}

1. Ananiev, D. E., Ananieva, K., Abdulova, G., Christova, N. And Videnova, E. (2002). Effects of abamectin on protein and RNA synthesis in primary leaves of Cucurbita pepo L. (zucchini). Bulgarian Journal of Plant Physiology. 28:85-91.

2. Apte, D.A. (2001). Pest management in polyhouse for gerbera (Gerbera jamensonii Hooker) M.Sc Agri. Thesis, MPKV, Rahuri.

3. Cox, D.L., Remick, M.D., Lasota, J.A. and Dybas, R.A. (1995). Toxicity of avermectins to Liriomyza trifolii (Diptera: Agromyzidae) larvae and adults. Journal of Economic Entomology. 88: 1415-1419.

4. Desai Nirjanjan Ravsaheb. (2013). Efficacy of different insecticides against leaf miner (Liriomyza trifolii Burgess) on cucumber and their effect on natural enemies. M.Sc (Agri) thesis, MPKV, Rahuri.

5. DowElanco. (1994). Spinosad Technical Guide. DowElanco, Indianapolis, IN, USA.

6. Fathipour, Y., Haghani, M., Talebi, A.A., Baniameri, V. and Zamani, A.A. (2006). Natural parasitism of Liriomyza sativae (Diptera: Agromyzidae) on cucumber under field and greenhouse conditions. IOBC/ WPRS Bulletin, 29: 155-160.

7. Ferguson, J.S. (2004). Development and stability of insecticide resistance in the leafminer Liriomyza trifolii (Diptera: Agromyzidae) to cyromazine, abamectin and spinosad. Journal of Economic Entomology. 97: 112-119.

8. Gahbiche, H. (2001). Effect of spinosad against $L$. trifolii and on its ectoparasitoid Diglyphus iseae. Phytoma. 538: 34-36.

9. Ganapathy, N., Durairaj, C., Karuppuchamy. (2010). Bioecology and management of serpentine leaf miner, L. trifolli (Burgess) in cowpea. Karnataka Journal of Agricultural Science. 23(1): 159-160.

10.Gawade, V.D. (2003). Evaluation of newer insecticides for their effectiveness against pest infesting gerbera (Gerbera jamensonii Hooker) under polyhouse condition. M.Sc (Agri) thesis, MPKV, Rahuri, pp 85.

11.IRAC (2015). Insecticide Resistance Action Committee,2015. Modes of action, http://www.irac-online.org/ eClassification

12.Kotze, D.J. and Dennill, G.B. (1996). The effect Liriomyza trifolii (Diptera: Agromyzidae) on fruit production and growth of tomatoes, Lycopersicon esculentum (Mill.) (Solanaceae). Journal of Applied Entomol-

\section{ogy. 120(4):231-235.}

13.Koul O. (1999). Insect growth regulating and antifeedant effects of neem extracts and azadirachtin on two aphid species of ornamental plants. Journal of Biosciences. 24:85-90.

14.Parrella, M.P. and Keil, C.B. (1985). Toxicity of methamidophos to four species of Agromyzidae. Journal of Agriculture Entomology. 2: 234-237.

15.Parrella, M.P., Jones, V.P., Youngman, R.R. and Lebeck, L.M. (1985). Effect of leaf mining and leaf stippling of Liriomyza spp. on photosynthetic rates of chrysanthemum. Annals of The Entomological Society of America. 78: 90-93.

16.Parrella, M.P. (1987). Biology of Liriomyza. Annual Review of Entomology. 32: 201-224.

17.Prijono, D., Robinson, M., Rauf, A., Bjorksten, T. and Hoffmann, A.A. (2004). Toxicity of chemicals commonly used in Indonesian vegetable crops to Liriomyza huidobrensis populations and Indonesian parasitoids Hemiptarsenus varicornis, Opius sp., and Gronotoma micromorpha, as well as the Australian parasitoids Hemiptarsenus varicornis and Diglyphus isaea. Journal of Economic Entomology. 97:11911197

18.Schuster, D.J. and Everett, P.H. (1983). Response of Liriomyza trifolii (Diptera: Agromyzidae) to insecticides on tomato. Journal of Economic Entomology. 76: 1170-1174.

19.Seal, D.R., Betancourt, R. and Sabines, C.M. (2002). Control of Liriomyza trifolii (Burgess) (Diptera: Agromyzidae) using various insecticides. Proceedings of Florida State Horticultural Society. 115: 308314.

20.Shashan Devkota., Dakshina R. Seal., Oscar E. Liburd., Scott Ferguson., Christine T. Waddill and Cliff G. Martin. (2016). Responses of Liriomyza trifolii (Diptera: Agromyzidae) to Chemical and Biorational insecticides. Florida Entomologist. 99(4):616-623.

21.Stark, J.D., Vargas, R.I. and Miller, N.W. (2004). Toxicity of spinosad in protein bait to three economically important tephritid fruit fly species (Diptera:Tephritidae) and their parasitoids (Hymenoptera: Braconidae). Journal of Economic Entomology. 97:911-915.

22.Udyana Panchagam. (2015). Package of practices of Dr. YSR Horticultural University publication.

23.Van Leeuwen, T., Van de Veire, M., Dermauw, W. and Tirry, L. (2006). Systemic toxicity of spinosad to the greenhouse whitefly, Trialeurodes vaporariorum and to the cotton leaf worm Spodoptera littoralis. Phytoparasitica. 34: 102-108.

24.Weintraub, P.G. (1999). Effect of cyromazine and abamectin on the leafminer, Liriomyza huidobrensis and its parasitoid, Diglyphus isaea in celery. Annals of Applied Biology. 135: 547-554.

25.Weintraub, P.G. (2001). Effects of cyromazine and abamectin on the pea leafminer Liriomyza huidobrensis (Diptera: Agromyzidae) and its parasitoid Diglyphus isaea (Hymenoptera: Eulophidae) in potatoes. Crop Protection. 20: 207-213.

26.ZREAC Proceedings (2016). Dr. YSR Horticultural University Zonal Research and Extension Action Council Proceedings held at Kadapa District for Andhra Pradesh State horticulture crops. 